\title{
Diversity of Ectomycorrhizal Fungi of Pinus densiflora Siebold et Zucc. Seedlings in a Disturbed Forest on Mt. Songni
}

\author{
Sim, Mi-Yeong and Ahn-Heum Eom* \\ Department of Biology Education, Korea National University of Education Chungbuk 363-791, Korea
}

\begin{abstract}
This study was conducted to investigate ectomycorrhizal (ECM) diversity on Pinus densiflora seedlings in a disturbed pine forest. Pine seedlings less than one year old were collected from disturbed and undisturbed sites in the Mt. Songni region. The belowground ECM fungal communities colonizing $P$. densiflora seedlings were studied using morphotyping and DNA sequencing. The relative abundance of ECM root tips was significantly higher in the undisturbed sites than in the disturbed sites, and the ECM species diversity was lower in the disturbed sites than in the undisturbed sites. In addition, the ECM community composition was significantly different in the disturbed and undisturbed forest sites.
\end{abstract}

Key words: Community, Disturbance, Ectomycorrhizal fungi, Pinus densiflora

\section{INTRODUCTION}

Ectomycorrhizal (ECM) fungi provide plants with increased access to resources and protect host plants from root pathogens and extreme soil conditions (Smith and Read 2008). In addition, ECM fungi have important effects on plant community structure (Horton et al. 1999, Parke et al. 1983). Although knowledge of the effects of ECM fungi on plant communities has increased over time, there is currently limited understanding of the dynamics of ECM communities. ECM fungal communities are known to be species-rich in species-poor stands of host trees within relatively small stands (Izzo et al. 2005). Various biotic and abiotic factors such as physical and chemical factors of the soil and interactions with soil organisms and host plants may affect ECM community structures (Dahlberg et al. 2001, Giardina and Rhoades 2001, Hagerman et al. 1999, Mah et al. 2001). However, the factors that influence and maintain the community structures of ECM fungi are poorly understood.

Natural disturbance, including forest fires, floods, and landslides, affects the biodiversity of ecosystems (White and Pickett 1985), and human activities often cause serious disturbance to forest ecosystems. The most type of disturbance caused by human activities results from topsoil removal, which influences the growth and survival of ECM fungi because it removes the majority of biological elements and destroys ECM fungal hyphae. Topsoil removal also causes changes in the soil environment, which can lead to the development of unfavorable conditions for ECM fungi (Parke et al. 1984, Perry et al. 1982). Under disturbed conditions, ECM fungal symbiosis is critical for the reestablishment of host plants after disturbance, as plant-fungal symbiosis results in enhanced nutrient and water uptake and increased tolerance to environmental stress (Amaranthus and Perry 1987, Malajczuk et al. 1994).

Much of our knowledge about the compositions of ECM fungi communities is based on observations of aboveground fungal sporocarps. However, sporocarp composition does not usually reflect the active fungal composition of ECM roots (Gardes and Bruns 1996, Jonsson et al. 1999a, van der Heijden et al. 1999). Therefore, the morphological characteristics of ECM root tips have been used to determine the identities of ECM species associated with plant roots (Agerer 1987-1998, Goodman et al. 1996-2000). However, the results of morphotyping of the ECM root tips were not consistent with those of molecular studies (Jonsson et al. 1999b, Sakakibara et al. 2002). Recent advances in molecular techniques have been applied to the studies of ECM fungal communities by using restriction fragment length polymorphism (RFLP) and DNA sequencing of the internal transcribed spacer (ITS) region of nuclear rDNA extracted from the ECM root tips (Egger 1995, Gardes and Bruns 1996, Horton and Bruns 2001, Park et al. 2006). In this study, we investigated the community structures of ECM fungi colonizing the roots of pine (Pinus densiflora) seedlings after severe forest disturbance in the Mt. Songni region, Korea and compared with ECM communities colonizing seedlings in an undisturbed pine forest near the disturbed sites.

\section{MATERIALS AND METHODS}

\section{Study Sites and Sampling}

ECM roots colonizing pine (Pinus densiflora) seedlings were collected from two disturbed sites and two undisturbed sites in a

\footnotetext{
* Corresponding author; Phone: +82-43-230-3767, e-mail: eomah@knue.ac.k
} 
pine forest near Mt. Songni in Korea $\left(6^{\circ} 35^{\prime} \mathrm{N}, 127^{\circ} 49^{\prime} \mathrm{E}\right)$. The mean annual precipitation in the area is $1,260 \mathrm{~mm}$, more than $50 \%$ of which occurs in the form of rain in June and July. The average annual temperature is $10.7^{\circ} \mathrm{C}$, and the monthly mean temperature is $-3.6^{\circ} \mathrm{C}$ in January and $24^{\circ} \mathrm{C}$ in August. In the disturbed area, top soils were removed approximately 10 years prior to the time of this study for building construction and as a result, only a few pine seedlings were growing at the site at the time of this study. We established two $10 \mathrm{~m}^{2}$ plots in the disturbed area and two $10 \mathrm{~m}^{2}$ plots in an undisturbed pine forest in close proximity to the disturbed sites for this study. The plots were located approximately $100 \mathrm{~m}$ apart. From each plot, we randomly selected and collected 10 one-year-old seedlings in June 2006. The seedlings and roots were placed in plastic bags, transported to the laboratory, and stored at $4^{\circ} \mathrm{C}$ until analysis within 2 weeks. We also collected soil samples at each sampling site. We homogenized the samples and sieved them to less than $2 \mathrm{~mm}$, after which soil subsamples were dried and their physical and chemical characteristics were evaluated using standard procedures. The study sites were characterized by higher concentrations of soil nutrients, including total nitrogen and phosphorus and lower soil $\mathrm{pH}$, in the undisturbed sites than in the disturbed sites (Table 1).

\section{Morphological and Molecular Identification of ECM}

The roots were gently washed and examined under stereomicroscopes. All the ECM root tips from each seedling were detached and the morphotypes of the ECM root tips were classified according to their morphological characteristics, including branching pattern, color, surface of mantle, and rhizomorphs (Brundrett et al. 1996, Rambold and Agerer 1997). The ECM morphotypes from individual seedlings were identified on the basis of molecular characteristics. A single ECM root tip representing each morphotype was selected and homogenized in a PCR tube using a micropestle. We extracted DNA from individual root tips using a DNeasy Plant mini kit (Qiagen Science, USA). We then PCR-amplified the ITS region of rDNA using the fungal-specific primer pair ITS1F and ITS4 (Gardes and Bruns 1993). Thermocycling for PCR was conducted as follows: $94^{\circ} \mathrm{C}$ for $3 \mathrm{~min}$ for 1 cycle, 94 for $1 \mathrm{~min}, 55^{\circ} \mathrm{C}$ for $1 \mathrm{~min}, 72^{\circ} \mathrm{C}$ for $1 \mathrm{~min}$ for 35 cycles, and $72^{\circ} \mathrm{C}$ for 7 min for 1 cycle. We then determined the nucleotide sequences for each root tip using an $\mathrm{ABI}$ PRISM 377 automatic sequencer (Perkin-Elmer, USA) and conducted a sequence similarity search in GenBank in the National Center for Biotechnology Information database using the Basic Local Alignment Search Tool algorithm. DNA sequences with 99\% similarity to those in GenBank were considered a match for species identification (Wurzburger et al. 2001). Sequences with lower levels of similarity were identified to the level of genus or family. The sequences were also aligned with CLUSTAL X 1.81 (Thompson et al. 1994) and used to generate a multiple alignment and neighborjoining phylogeny (Saitou and Nei 1987) using Rhizophus oryzae as an outgroup.

\section{Statistical Analysis}

The relative abundance of an ECM fungal taxon in an individual seedling was calculated by dividing the number of root tips for each taxon by the total number of ECM fungi examined. Data on the relative abundance of ECM morphotypes for each seedling were used for analysis of ECM community structure. We analyzed the data using one-way analysis of variance (ANOVA) using the statistical package SPSS-WIN (SPSS Inc., USA). The Shannon-Wiener index of diversity was also calculated to estimate diversity, and canonical correspondence analysis (CCA) was performed to compare the compositions of ECM communities within and among sites and to determine the correlation between the community composition and soil properties at the sites.

\section{RESULTS}

We collected a total of 40 seedlings from the study sites, and classified 5155 ECM tips using their morphological characteristics. One to four ECM morphotypes were found on each seedling, and a total of 44 morphotypes were identified on the 40 seedlings. We successfully PCR-amplified DNA from 94 ECM root tips: 36 tips from disturbed sites and 58 tips from undisturbed sites, and identified 41 different ECM taxa using DNA sequence analysis (Fig. 1). Basidiomycetous ECM fungi comprised $80 \%$ of all identified ECM fungal species, while the remaining $20 \%$ of fungi were ascomycetous species. The five most abundant species were Rhizopogon luteolus, Suillus luteus, S. bovines, Tomentella ellisii, and Oidiodendron 1 , which together comprised $41 \%$ of the ECM fungi in the root tips. However, Tremellodendron pallidum was the most frequently occurring species, having colonized $20 \%$ of the root samples.

Table 1. Soil chemical properties of the study sites (Mean \pm S.E.)

\begin{tabular}{cccccc}
\hline \hline \multicolumn{1}{c}{ Site } & $\mathrm{pH}$ & Organic matter (\%) & Total N (\%) & Available P $(\mathrm{mg} / \mathrm{kg})$ & CEC $(\mathrm{cmol}+/ \mathrm{kg})$ \\
\hline Undisturbed forest (F) & $4.80 \pm 0.20$ & $2.0 \pm 1.2$ & $0.10 \pm 0.05$ & 2.0 & $6.60 \pm 0.66$ \\
Disturbed (D) & $5.70 \pm 0.15$ & $0.2 \pm 0.1$ & $0.01 \pm 0.00$ & 1.0 & $1.97 \pm 0.11$ \\
\hline
\end{tabular}




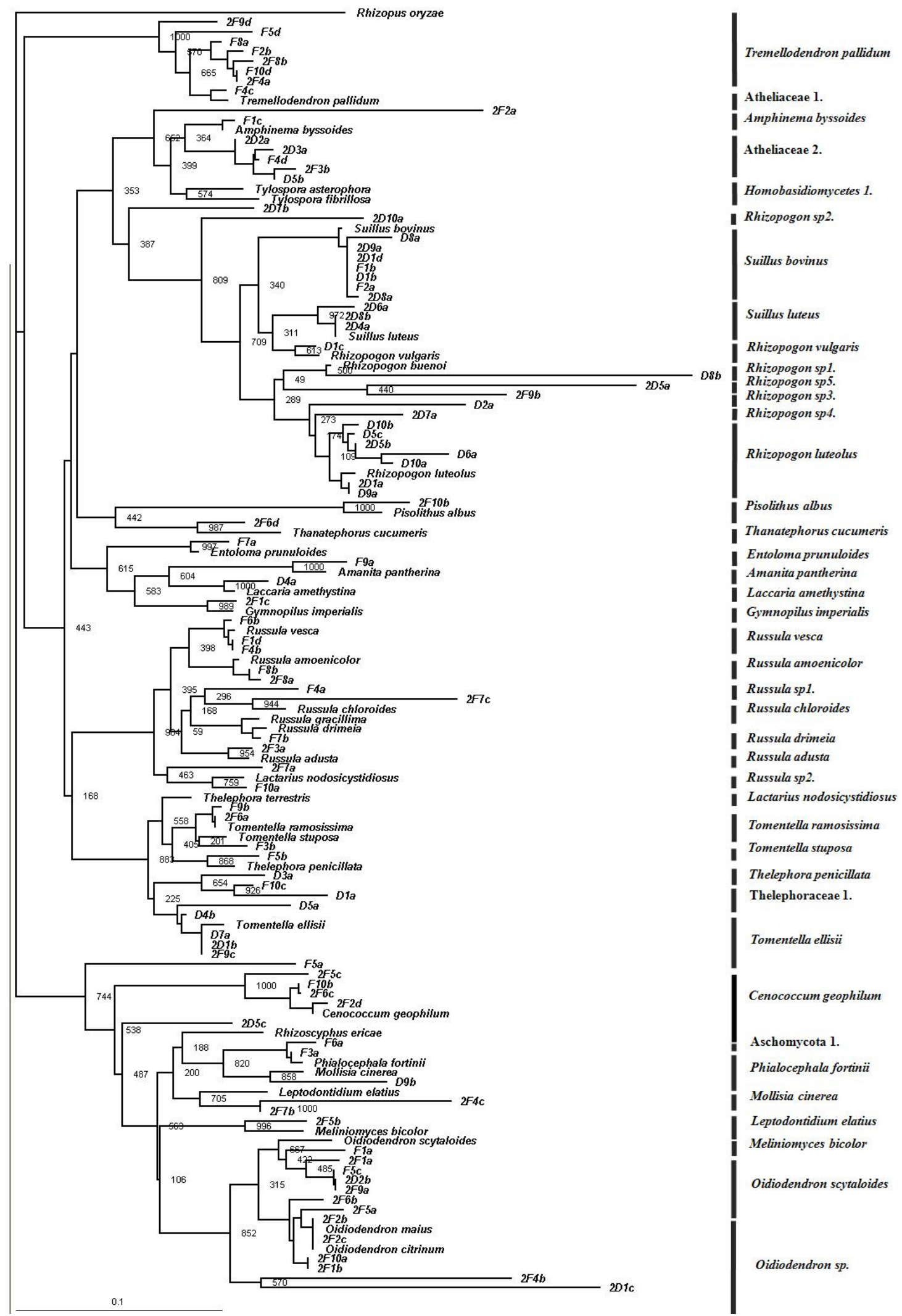

Fig. 1. Neighbor-joining tree illustrating the taxonomic affinities of the sequences obtained from the ECM fungi. Rhizopus stolonifer was used as an outgroup. 
There were significantly more ECM fungal species in the undisturbed sites (30 species) than in the disturbed sites (17 species; Fig. 2, Table 2). Only six species, namely, Oidiodendron 1, S. bovines, Tomentella ramosissima, O. scytaloides, Atheliaceae 2, and Telephoraceae 1, were found at both types of sites. Three of the species of ECM fungi that were found at both types of sites were significantly higher relative abundances in the disturbed sites, and



(a)

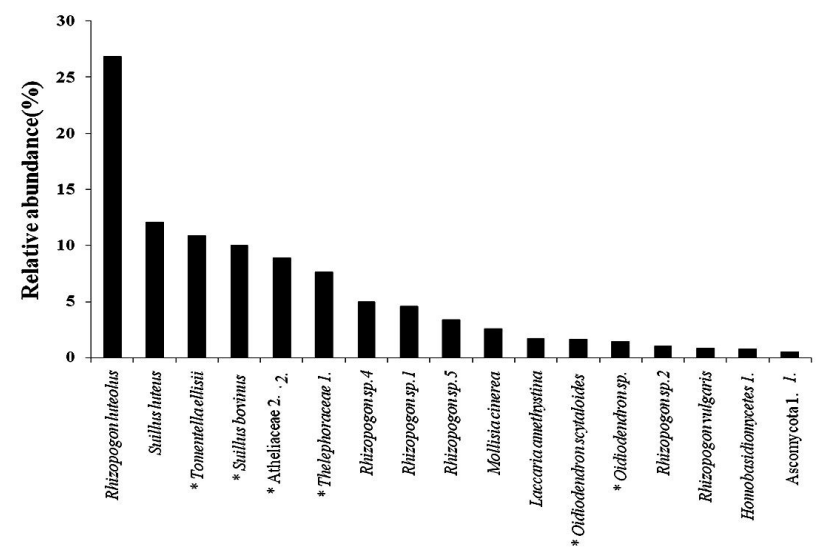

(b)

Fig. 2. Relative abundance of ECM morphotypes colonizing roots of Pinus densiflora seedlings in undisturbed forest (a) and disturbed (b) sites. Asterisks on the fungal species indicate the ECM species found in both disturbed and forest sites.

Table 2. Species diversity (H'), evenness and richness of ECM fungi colonizing seedlings of Pinus densiflora in the study sites

\begin{tabular}{lcccccc}
\hline \hline & \multicolumn{3}{c}{ Mean } & & \multicolumn{2}{c}{ ANOVA } \\
\cline { 2 - 3 } \cline { 5 - 6 } \cline { 5 - 6 } & Undisturbed & Disturbed & & $\mathrm{F}$ & $\mathrm{P}$ \\
\hline Number of ECM root tips & 128.1 & 129.7 & & 0.07 & 0.93 \\
Species diversity & 0.8 & 0.3 & & 14.5 & $<0.01$ \\
Species evenness & 0.8 & 0.4 & & 12.6 & 0.01 \\
Species richness & 2.9 & 1.8 & & 15.2 & $<0.01$ \\
\hline
\end{tabular}

one species was significantly more abundant in the undisturbed sites. We found 24 species only in the disturbed sites, and 11 species only in the disturbed sites. The ECM communities of the disturbed sites were dominated by species belonging to the genera Rhizopogon and Suillus, but fungal species in the family Russulaceae dominated in the undisturbed sites. Tremellodendron pallidum was the most abundant ECM fungus in the roots of pine seedlings in undisturbed sites, while Suillus luteus was the most abundant species in disturbed sites. T. pallidum and Rhizopogon luteolus were the most frequently occurring ECM species in undisturbed and disturbed sites, respectively.

The species diversity, species evenness, and species richness were significantly higher in undisturbed sites than in disturbed sites (Table 2). However, the number of ECM root tips was not significantly different in the two types of sites. Therefore, compared to the undisturbed sites, ECM fungal communities in disturbed sites were characterized by lower number of species and evenness, indicating that only a few species dominated the community. This suggests that the removal of topsoil caused a significant change in the ECM fungal community structures in the disturbed sites. CCA ordination of the ECM fungal communities separated the communities found in individual seedlings into two distinct groups, namely, those from the undisturbed and disturbed sites, according to their soil properties (Fig. 3). The individual eigenvalues of axes 1 and 2 were 0.823 and 0.623 , respectively, and these two axes explained $8 \%$ of the variation in the ECM communities of pine seedlings.

\section{DISCUSSION}

We investigated how forest disturbance influences the structure

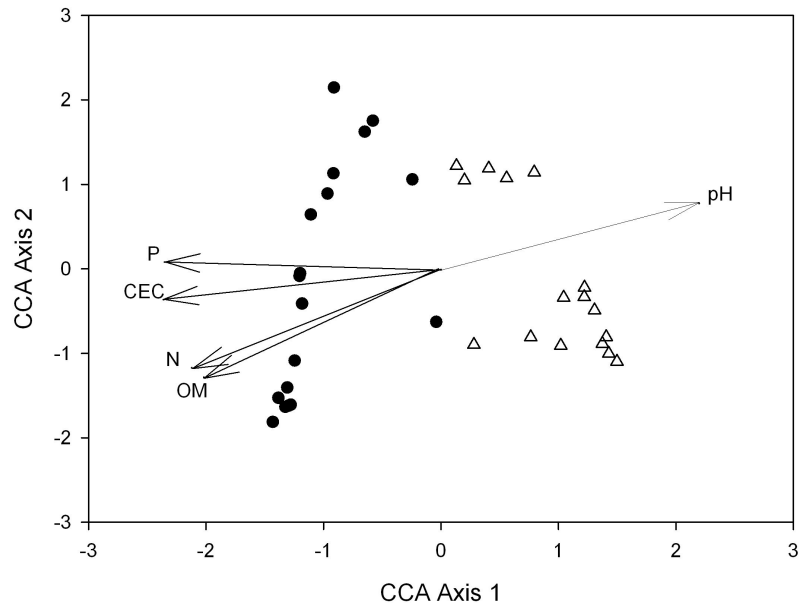

Fig. 3. PCA ordination of ECM communities colonizing roots of Pinus densiflora from disturbed (triangles) and undisturbed (circles) sites. 
of ECM communities in pine seedling in disturbed and undisturbed sites by performing morphological and molecular identification. The environment of the study sites had been greatly modified due to a severe forest disturbance. Disturbance influences biodiversity and ecosystem functioning (Sousa 1979). Although weak disturbances strengthen the diversity of an ecosystem, strong disturbances reduce the diversity of an ecosystem through an increase of a particular species and reducing species richness. Most forest disturbances due to human activities, such as wood cutting or road construction, are severe and heavily influence biotic and abiotic environments (Ponder and Tadros 2002). In this study, the number of ECM root tips was not significantly different between the disturbed and undisturbed forest areas, but ECM species richness and diversity were lower in disturbed sites, where the physical and chemical characteristics of soils had been significantly altered due to soil removal. The results of this study are consistent with those of previous studies that reported a decrease in the ECM fungal diversity after strong disturbances (Erland and Taylor 2002). In this study, the composition of the ECM fungal community in the disturbed sites was different from that of the undisturbed forest sites, and environmental factors such as the physical and chemical characteristics of the soil were significantly correlated with the distributions of the ECM communities; this suggests that species capable of adapting to the modified environment survived and became dominant in disturbed sites. After the removal of ECM fungi along with the top soils, rapidly growing fungi colonized the sites, and the ECM fungi that could adapt to water- and nutrient-poor environments survived.

In this study, the dominant ECM fungal species colonizing the roots of seedlings in disturbed sites, Rhizopogon and Suillus sp., are known to be early-stage species of ECM fungal succession; they colonize young roots, derive small amounts of carbon from their hosts, and require low concentrations of mineral nutrients (Colpaert et al. 1996). Basidiomycetous fungi in the family Russulasceae are common ECM fungi in mature stable temperate coniferous forests; they require greater amounts of carbon and nutrients and colonize via hyphae (Horton and Bruns 2001). In this study, Russula sp., known to be late-stage species, were dominant in undisturbed forest sites. Baar et al. (1999) reported similar community changes of ECM colonizing Pinus muricata after a forest fire, and Rhizopogon species were also the dominant ECM fungi for Douglas fir and pine seedlings in disturbed forest soils (Bradbury 1998). Rhizopogon species provide seedlings with tolerance to low-nutrient conditions and drought stress (Chu Chou and Grace 1984, Chu Chou and Grace 1985, Parke et al. 1983).

Although the undisturbed sites were within $1 \mathrm{~km}$ of the disturbed sites, most species found in the former could not be found in the latter. This could be due to extreme environmental conditions in the disturbed sites that hinder hyphal growth or competitive exclusion by fungal species in the disturbed areas. However, in our study, basidiomycetous ECM fungi were dominant in both sites, whereas in some previous studies, ascomycetous ECM fungi became dominant after fires or clear-cut logging (Byrd et al. 2000, Mah et al. 2001, Taylor and Bruns 1999).

Natural organisms surviving in disturbed ecosystems are often subjected to selective pressures for increased resistance to environmental stresses. In the present study, we describe the ECM fungi that colonized roots of pine seedlings collected in disturbed sites in Korea. These fungi may have been adapted to tolerate harsh environmental conditions and therefore were able to protect pine seedlings from these environmental stresses. Such adapted-ECM fungushost plant combinations might be suitable for the revegetation of disturbed sites. In a future study, we will inoculate native ECM fungi isolated from roots or sporocarps into plants to examine the effects of these ECM fungi on plant growth under different conditions. This information may provide useful information to guide future revegetation efforts.

\section{ACKNOWLEDGMENTS}

This work was supported by a Korea Research Foundation Grant funded by the Korean Government (MOE-HRD, Basic Research Promotion Fund: KRF-2006-003-C00277)

\section{LITERATURE CITED}

Agerer R. 1987-1998. Colour Atlas of Ectomycorrhizae. Einhorn, Schwawisch-Gmund.

Amaranthus MP, Perry DA. 1987. Effect of soil transfer on ectomycorrhiza formation and survival and growth of conifer seedlings in disturbed forest sites. Can J For Res 17: 944-950.

Baar J, Horton TR, Kretzer AM, Bruns TD. 1999. Mycorrhizal colonization of Pinus muricata from resistant propagules after a stand-replacing wildfire. New Phytol 143: 409-418.

Bradbury SM. 1998. Ectomycorrhizas of lodgepole pine (Pinus contorta) seedlings originating from seed in southwestern Alberta cut blocks. Can J Bot 76: 213-217.

Brundrett M, Bougher N, Dell B, Grove T, Malajczuk N. 1996. Working with Mycorrhizas in Forestry and Agriculture, ACIAR Monograph 32. Australian Centre for International Agricultural Research, Canberra, Australia.

Byrd KB, Parker VT, Vogler DR, Cullings KW. 2000. The influence of clear-cutting on ectomycorrhizal fungus diversity in a lodgepole pine (Pinus contorta) stand, Yellowstone National Park, Wyoming, and Gallatin National Forest, Montana. Can J Bot 78: 149-156.

Chu Chou M, Grace LJ. 1984. Cultural characteristics of Rhizopogon spp associated with Pinus radiata seedlings. New Zealand J Bot 
22: $35-42$.

Chu Chou M, Grace LJ. 1985. Comparative efficiency of the mycorrhizal fungi Laccaria-Laccata Hebeloma-Crustuliniforme and Rhizopogon species on growth of Radiata pine seedlings. New Zealand J Bot 23: 417-424.

Colpaert JV, Van LA, Van AJA. 1996. Carbon and nitrogen allocation in ectomycorrhizal and non-mycorrhizal Pinus sylvestris L. seedlings. Tree Physiol 16: 787-793.

Dahlberg A, Schimmel J, Taylor AFS, Johannesson H. 2001. Post-fire legacy of ectomycorrhizal fungal communities in the Swedish boreal forest in relation to fire severity and logging intensity. Biol Cons 100: 151-161.

Deacon JW, Fleming LV. 1992. Interactions of Ectomycorrhizal Fungi. In Mycorrhizal Functioning: an Integrative Plant-fungal Process (Allen MF, ed). Springer-Verlag, Berlin, pp 249-300.

Egger KN. 1995. Molecular analysis of ectomycorrhizal fungal communities. Can J Bot 73: S1415-S1422.

Erland S, Taylor AF. 2002. Diversity of ectomycorrhizal fungal communities in relation to the abiotic environment. In Mycorrhizal Ecology (van der Heijden MG, Sanders IR, eds). Springer, Berlin, Germany, pp 163-200.

Gardes M, Bruns TD. 1993. ITS primers with enhanced specificity for basidiomycetes-application to the identification of mycorrhizae and rusts. Mol Ecol 2: 113-118.

Gardes M, Bruns TD. 1996. Community structure of ectomycorrhizal fungi in a Pinus muricata forest: Above- and below-ground views. Can J Bot 74: 1572-1583.

Giardina CP, Rhoades CC. 2001. Clear cutting and burning affect nitrogen supply, phosphorus fractions and seedling growth in soils from a Wyoming lodgepole pine forest. Forest Ecol Mangag 140: 19-28.

Goodman DM, Durall DM, Trofymow JA, Berch SM. 1996-2000. Concise descriptions of North American Ectomycorrhizae. Mycologue Publications, Victoria, BC.

Hagerman SM, Jones MD, Bradfield GE, Gillespie M, Durall DM. 1999. Effects of clear-cut logging on the diversity and persistence of ectomycorrhizae at a subalpine forest. Can J Forest Res 29: 124-134.

Horton TR, Bruns TD. 2001. The molecular revolution in ectomycorrhizal ecology: Peeking into the black-box. Mol Ecol 10: 1855-1871.

Horton TR, Bruns TD, Parker VT. 1999. Ectomycorrhizal fungi associated with Arctostaphylos contribute to Pseudotsuga menziesii establishment. Can J Bot 77: 93-102.

Izzo A, Agbowo J, Bruns TD. 2005. Detection of plot-level changes in ectomycorrhizal communities across years in an old-growth mixed-conifer forest. New Phytol 166: 619-629.

Jonsson L, Dahlberg A, Nilsson MC, Zackrisson O, Kren O. 1999a. Ectomycorhizal fungal communities in late-successional Swedish boreal forests, and the composition following wildfire. Mol Ecol 8: 205-215.

Jonsson T, Kokalj S, Finlay R, Erland S. 1999b. Ectomycorrhizal community structure in a limed spruce forest. Mycol Res 103: 501-508.

Mah K, Tackaberry LE, Egger KN, Massicotte HB. 2001. The impacts of broadcast burning after clear-cutting on the diversity of ectomycorrhizal fungi associated with hybrid spruce seedlings in central
British Columbia. Can J For Res 31: 224-235.

Malajczuk N, Riddell P, Brundrett M. 1994. Role of ectomycorrhizal fungi in minesite reclamation. In Mycorrhizae and Plant Health (Pfleger FL, Linderman RG, eds). APS Press, St. Paul, MN, pp 83-100.

Park SH, Jeong HS, Lee YM, Eom AH, Lee CS. 2006. Identification of ectomycorrhizal fungi from Pinus densiflora seedlings at an abandoned coal mine. J Ecol Field Biol 29: 143-149.

Parke JL, Linderman RG, Black CH. 1983. The Role of Ectomycorrhizas in drought tolerance of douglas-fir Pseudotsuga menziesii Seedlings. New Phytol 95: 83-96.

Parke JL, Linderman RG, Trappe JM. 1984. Inoculum potential of ectomycorrhizal fungi in forest soils of southwest Oregon and northern California. Forest Science 30: 300-304.

Perry DA, Meyer MM, Egeland D, Rose SL, Pilz D. 1982. Seedling growth and mycorrhizal formation in clear cut and adjacent undisturbed soils in Montana USA a greenhouse bioassay. For Ecol Manag 4: 261-274.

Ponder F, Tadros M. 2002. Phospholipid fatty acids in forest soil four years after organic matter removal and soil compaction. Appl Soil Ecol 19: 173-182.

Rambold G, Agerer R. 1997. DEEMY- The concept of a characterization and determination system for ectomycorrhizae. Mycorrhiza 7: 113-116.

Saitou N, Nei M. 1987. The neighbor-joining method: a new method for reconstructing phylogenetic tree. Mol Biol Evol 4: 406-425.

Sakakibara SM, Jones MD, Gillespie M, Hagerman SM, Forrest ME, Simard SW, Durall DM. 2002. A comparison of ectomycorrhiza identification based on morphotyping and PCR-RFLP analysis. Mycol Res 106: 868-878.

Smith SE, Read DJ. 2008. Mycorrhizal Symbiosis, 3rd Ed. Academic Press, London.

Sousa WP. 1979. Disturbance in marine intertidal boulder fields: the nonequilibrium maintenance of species diversity. Ecology 60: 12251239.

Taylor DL, Bruns TD. 1999. Community structure of ectomycorrhizal fungi in a Pinus muricata forest: Minimal overlap between the mature forest and resistant propagule communities. Mol Ecol 8: 1837-1850.

Thompson JD, Higgins DG, Gibson TJ. 1994. CLUSTAL X: Improving the sensitivity of multiple sequence alignment though sequence weighting, position-specific gap penalties and weight matrix choice. Nucleic Acid Res 26: 179-182.

van der Heijden EW, de VFW, Kuyper TW. 1999. Mycorrhizal associations of Salix repens L. communities in succession of dune ecosystems. I. Above-ground and below-ground views of ectomycorrhizal fungi in relation to soil chemistry. Can J Bot 77: 1821-1832.

White PS, Pickett STA. 1985. Natural disturbance and patch dynamics: an introduction. In The Ecology of Natural Disturbance and Patch Dynamics. (Pickett STA, White PS, eds). Academic Press, New York, pp 3-13.

Wurzburger N, Bidartondo MI, Bledsoe C. 2001. Characterization of Pinus ectomycorrhizas from mixed conifer and pygmy forests using morphotyping and molecular methods. Can J Bot 79: 1211-1216.

(Received January 29, 2009; Accepted February 10, 2009) 